\title{
Low Magnesium Exacerbates Osteoporosis in Chronic Kidney Disease Patients with Diabetes
}

\author{
Jui-Hua Huang, ${ }^{1}$ Fu-Chou Cheng, ${ }^{2}$ and Hsu-Chen $\mathrm{Wu}^{3}$ \\ ${ }^{1}$ Department of Community Health, Chia-Yi Christian Hospital, Chiayi 600, Taiwan \\ ${ }^{2}$ Stem Cell Center, Department of Medical Research, Taichung Veterans General Hospital, Taichung 402, Taiwan \\ ${ }^{3}$ Division of Nephrology, Department of Internal Medicine, Changhua Christian Medical Foundation Erlin Christian Hospital, \\ Changhua 526, Taiwan \\ Correspondence should be addressed to Hsu-Chen Wu; 82128@cch.org.tw
}

Received 16 October 2014; Revised 19 January 2015; Accepted 9 March 2015

Academic Editor: Francesco Pantano

Copyright (C) 2015 Jui-Hua Huang et al. This is an open access article distributed under the Creative Commons Attribution License, which permits unrestricted use, distribution, and reproduction in any medium, provided the original work is properly cited.

\begin{abstract}
The aim of this study is to investigate the impact of serum $\mathrm{Mg}$ on bone mineral metabolism in chronic kidney disease (CKD) patients with or without diabetes. A total of $56 \mathrm{CKD}$ patients not receiving dialysis were recruited and divided into two groups, one group of $27 \mathrm{CKD}$ patients with diabetes and another group of $29 \mathrm{CKD}$ patients without diabetes. Biochemical determinations were made, and the estimated glomerular filtration rate (eGFR) was measured. Bone mineral density was measured by dual-energy X-ray absorptiometry. Serum Mg was inversely correlated with serum $\mathrm{Ca}(P=0.023)$ and positively correlated with serum parathyroid hormone (PTH) $(P=0.020)$, alkaline phosphatase $(P=0.044)$, and phosphate $(P=0.040)$ in the CKD patients with diabetes. The CKD patients with diabetes had lower serum albumin and a higher proportion of hypomagnesemia and osteoporosis than the nondiabetic patients did $(P<0.05)$. Serum $\mathrm{Mg}$ was inversely correlated with eGFR in the CKD patients with or without diabetes $(P<0.05)$. Serum Mg showed an inverse correlation with 25-hydroxyvitamin $\mathrm{D}$ in CKD patients without diabetes $(P=0.006)$. Furthermore, the diabetic CKD patients with low serum $\mathrm{Mg}$ had a lower iPTH $(P=0.007)$ and a higher serum $\mathrm{Ca} / \mathrm{Mg}$ ratio $(P<0.001)$ than the other CKD patients. The lower serum $\mathrm{Mg}$ subgroup showed a higher incidence of osteoporosis than the moderate and higher serum Mg subgroups did (66.7\%, 39.4\%, and 29.4\%, resp.). In conclusion, low serum Mg may impact iPTH and exacerbates osteoporosis in CKD patients, particularly with diabetes.
\end{abstract}

\section{Introduction}

Osteoporosis is a skeletal disorder characterized by a low bone mass and disruption of bone architecture that leads to decreased bone strength and increased fracture risk [1]. Many factors are associated with osteoporosis, including nutritional, hormonal, and clinical factors $[1,2]$. Low calcium (Ca) status is associated with a reduced bone mass and osteoporosis $[3,4]$. Vitamin D deficiency impairs the absorption of $\mathrm{Ca}$ and leads to osteomalacia [5]. Magnesium $(\mathrm{Mg})$ is also a major regulator of bone homeostasis [6]. Low Mg levels may impair the activity of parathyroid hormones (PTH) [2] and reduce serum vitamin $\mathrm{D}$ levels $[7,8]$. In addition, chronic kidney disease (CKD) will cause abnormality of bone mineral metabolism and therefore result in complications of bone disease [9-11]. Besides, serum Mg levels may be reduced or raised with poor diabetic control or renal functional decline $[12,13]$, which may exacerbate bone disease [6]. However, the effect of $\mathrm{Mg}$ status, dietary $\mathrm{Mg}$, serum $\mathrm{Mg}$, and urine $\mathrm{Mg}$ in patients with diabetic nephropathy or CKD on $\mathrm{Ca}$ and bone metabolism remains unclear.

Low or high serum $\mathrm{Mg}$ levels may result in unwanted neuromuscular, cardiac, nervous, metabolic, or bone disorders $[14,15]$. A deficit in $\mathrm{Mg}$ increases the risks for several diseases, including diabetes, hypertension, and cardiovascular diseases $[16,17]$. Moreover, $\mathrm{Mg}$ deficiency is associated with low bone mass and osteoporosis [6]. Indeed, $\mathrm{Mg}$ deficiency affects the secretion and sensitivity of PTH. Therefore, low magnesium status reduces the activity of the 25-hydroxycholecalciferol1-hydroxylase resulting in low serum concentrations of 
1,25-dihydroxyvitamin $\mathrm{D}\left(1,25(\mathrm{OH})_{2} \mathrm{D}\right)$ and $\mathrm{Ca}[2,7,8]$. In contrast, hypermagnesemia causes vasodilation and neuromuscular blockade [14]. Furthermore, high serum Mg levels may inhibit parathyroid hormone (PTH) secretion and also have adverse biologic effects on bone mineral metabolism [6]. However, the relationship between low or high serum Mg levels with PTH levels, vitamin D, and bone mineral metabolism remains unclear.

Chronic kidney disease causes a progressive decline in renal function over time. In the early stages, there may be no specific symptoms. Moderate-severe renal decline causes abnormality in bone and mineral metabolism, which is one of the common complications in patients with CKD [9-11]. Abnormal levels of $\mathrm{PTH}$, serum vitamin $\mathrm{D}$, serum phosphate (P), and serum Ca contribute to renal bone disease [9-11]. Serum $\mathrm{Mg}$ levels may raise with renal functional decline [12], and this eventually may be harmful to bone health [6]. In addition, diabetes is related to an increased risk of hypomagnesemia and osteoporosis $[18,19]$. The patients with diabetes presented lower levels of serum Ca, vitamin D, PTH, and serum $\mathrm{Mg}[20,21]$. Furthermore, lower PTH concentration resulted in low bone formation, which may increase the risk of vertebral fractures in diabetes patients of both sexes [22]. However, there is little information about the effects of $\mathrm{Mg}$ on $\mathrm{PTH}, \mathrm{Ca}$, vitamin $\mathrm{D}$, and bone metabolism in patients with CKD, particularly in diabetic CKD patients.

Now growing evidence shows that low Mg is associated with diabetes and nephropathy $[13,23]$. Low $\mathrm{Mg}$ and impaired secretion and function of PTH decrease the levels of $1,25(\mathrm{OH})_{2} \mathrm{D}$, cause low serum $\mathrm{Ca}$, and are linked to bone and mineral metabolism disorders [2, 24]. Thus, low Mg may exacerbate bone disease in patients with CKD. However, it remains unclear whether moderate-severe CKD patients with diabetes still have a higher prevalence of hypomagnesemia than those of nondiabetic CKD patients because serum $\mathrm{Mg}$ levels may rise with renal function decline. Moreover, differences in the correlations between serum $\mathrm{Mg}$ with $\mathrm{Ca}$, $\mathrm{PTH}$, and bone mineral metabolism between CKD patients with and without diabetes have not been fully explored.

In the present study, serum $\mathrm{Mg}$ levels, bone mineral metabolism parameters, bone mineral density, and renal function indicators were measured. The objective of this study was to evaluate the impacts of serum Mg levels on PTH and bone mineral metabolic parameters among CKD patients with or without diabetes.

\section{Materials and Methods}

2.1. Study Design and Subjects. This study involved 56 stage 3-5 CKD patients not receiving dialysis who were divided into two groups as $27 \mathrm{CKD}$ with diabetes and $29 \mathrm{CKD}$ without diabetes. Patients were residents in a rural area and were diagnosed with chronic kidney disease at the hospital clinic of Central Taiwan. All patients were without a history of symptomatic ischaemic heart disease, heart failure, liver disease, current malignancy, and hypoparathyroidism. The study protocol was approved by the Changhua Christian Hospital Institutional Review Board (CCHIRB 090605), and informed consent was obtained from each participant.
2.2. Biochemical Determination. Blood samples were collected after an overnight fasting for the determinations of serum $\mathrm{Mg}, \mathrm{Ca}, \mathrm{P}$, intact $\mathrm{PTH}$ (iPTH), alkaline phosphatase (ALP), 25-hydroxyvitamin D (25(OH)D), and 1,25dihydroxyvitamin $\mathrm{D}\left(1,25(\mathrm{OH})_{2} \mathrm{D}\right)$ levels. Serum $\mathrm{Mg}$ levels between 1.82 and $2.31 \mathrm{mg} / \mathrm{dL}$ were defined as the normal range [25]. For patients with stages 3,4 , and 5 CKD, PTH should be maintained in the range of $35-70 \mathrm{pg} / \mathrm{mL}, 70-110 \mathrm{pg} / \mathrm{mL}$, and $150-300 \mathrm{pg} / \mathrm{mL}$, respectively [26]. For patients with stages 3 to $4 \mathrm{CKD}$, serum Ca should be maintained within normal range, 8.9-10.1 mg/dL, and serum P should be within $2.7-4.6 \mathrm{mg} / \mathrm{dL}$ [26]. For patients with stage 5 CKD, serum Ca should be 8.4$9.5 \mathrm{mg} / \mathrm{dL}$, and serum P target should be $3.3-5.5 \mathrm{mg} / \mathrm{dL}$ [26]. For patients with stages 3 to $5 \mathrm{CKD}$, Ca-P product should be $<55 \mathrm{mg}^{2} / \mathrm{dL}^{2}$ [26]. The reference range of ALP is $50-136$ (U/L) for laboratory used. Furthermore, vitamin D deficiency is defined as a serum $25(\mathrm{OH}) \mathrm{D}$ level of less than $20 \mathrm{ng} / \mathrm{mL}$ and vitamin D insufficiency is defined as a serum $25(\mathrm{OH}) \mathrm{D}$ level of 20 to $30 \mathrm{ng} / \mathrm{mL}$ [27]. Serum $1,25(\mathrm{OH})_{2} \mathrm{D}$ deficiency is defined as a serum $1,25(\mathrm{OH})_{2} \mathrm{D}$ level of less than $25.1 \mathrm{ng} / \mathrm{mL}$ for laboratory used.

In addition, based on the formula recommended by the Taiwan Society of Nephrology, estimated glomerular filtration rate (eGFR) was calculated as eGFR ( $\mathrm{mL} / \mathrm{min} / 1.73 \mathrm{~m} 2)$ (Simplified Modification of Diet in Renal Disease $($ MDRD $))=$ $186 \times$ serum creatinine $e^{-1.154} \times$ Age $^{-0.203}$ in men, and $186 \times$ serum creatinine $\mathrm{e}^{-1.154} \times$ Age $^{-0.203} \times 0.742$ in women. The definition of chronic kidney disease (CKD) stages was based upon guidelines for the management of CKD [28]. Blood urea nitrogen (BUN) was also measured.

2.3. Bone Mineral Density. Bone mineral density at the left femoral neck, right femoral neck, and lumbar spine (L1-L4) was measured by dual-energy X-ray absorptiometry. Results were expressed as $\mathrm{g} / \mathrm{cm}^{2}$ or as a $T$-score, which represents the number of standard deviations (SD) of the difference between a patient's BMD and that of a gender-matched young adult reference population. By definition from the World Health Organization, we have the following: (1) normal: $T$-Score at or above $-1.0 \mathrm{SD}$; (2) osteopenia: $T$-Score between -1.0 and $-2.5 \mathrm{SD}$; and (3) osteoporosis: $T$-Score at or below $-2.5 \mathrm{SD}$ [29].

2.4. Statistical Analysis. The Kolmogorov-Smirnov test was used to assess the normality of the distribution of investigated parameters. Continuous data were expressed (mean \pm SD) and differences were tested by a 2 -tailed $t$-test. Categorical data were analyzed by the Chi-square test. Continuous data of skewed distribution were presented in median, and range (25th pctl-75th pctl) and differences were examined by the Wilcoxon rank-sum test or the Kruskal-Wallis test. Multivariate analysis of the general linear model was used to analyze the association between variables. The serum $\mathrm{Mg}$, bone metabolism parameters, serum $\mathrm{Ca} / \mathrm{Mg}$ ratio, serum $\mathrm{Ca} \times \mathrm{P}$ values, and renal function indicators were $\log$ transformed before analysis because of the data's skewed distribution. Multiple regression was used to analyze all variables and presented in unstandardized coefficients $(B)$, 
TABLE 1: Characteristics of the 56 nondialysis CKD patients with or without diabetes.

\begin{tabular}{|c|c|c|c|c|}
\hline Variables & Total $(n=56)$ & Diabetes $(n=27)$ & Nondiabetes $(n=29)$ & $P$ \\
\hline Age (y) & $69.0(58.8-75.8)$ & $68.0(62.0-77.0)$ & $70(57.0-74.5)$ & 0.928 \\
\hline \multicolumn{5}{|l|}{ Gender } \\
\hline Female & $24(42.9)$ & $15(55.6)$ & $9(31.0)$ & \multirow{2}{*}{0.064} \\
\hline Male & $32(57.1)$ & $12(44.4)$ & $20(69.0)$ & \\
\hline Estimated GFR (mL/min) & $16.5(10.5-28.8)$ & $13.7(9.4-29.8)$ & $18.4(12.0-24.8)$ & 0.302 \\
\hline \multicolumn{5}{|l|}{ Chronic kidney disease } \\
\hline Stage 3 & $13(23.2)$ & $7(25.9)$ & $6(20.7)$ & \multirow{3}{*}{0.102} \\
\hline Stage 4 & $18(55.4)$ & $5(18.5)$ & $13(44.8)$ & \\
\hline Stage 5 & $25(44.6)$ & $15(55.6)$ & $10(34.5)$ & \\
\hline Albumin (g/dL) & $3.8 \pm 0.4$ & $3.7 \pm 0.4$ & $3.9 \pm 0.4$ & 0.046 \\
\hline \multicolumn{5}{|l|}{ Serum Mg $(\mathrm{mmoL} / \mathrm{L})$} \\
\hline$<1.82 \mathrm{mg} / \mathrm{dL}$ low & $6(10.7)$ & $6(22.2)$ & - & \multirow{3}{*}{0.023} \\
\hline $1.82-2.31 \mathrm{mg} / \mathrm{dL}$ normal & $33(58.9)$ & $13(48.1)$ & $20(69.0)$ & \\
\hline$>2.31 \mathrm{mg} / \mathrm{dL}$ high & $17(30.4)$ & $8(29.6)$ & $9(31.0)$ & \\
\hline \multicolumn{5}{|l|}{ Osteoporosis } \\
\hline With & $22(39.3)$ & $15(55.6)$ & $7(24.1)$ & \multirow{2}{*}{0.016} \\
\hline Without & $34(60.7)$ & $12(44.4)$ & $22(75.9)$ & \\
\hline
\end{tabular}

(1) eGFR, estimated glomerular filtration rate.

(2) Comparisons of continuous data between two groups were analyzed by Wilcoxon rank-sumtest. Data are median and range (25th pctl-75th pctl). The $t$ test was used for the difference in the means of two groups. Data are means \pm SD.

(3) Categorical data were analyzed by the Chi-square test. When cells have expected count less than 5, data were analyzed by Fisher's Exact test. Data are number (n), percent (\%).

(4) A $P$ value less than 0.05 was considered statistically significant.

in standardized coefficients $(\beta)$, and at a 95\% confidence interval (CI) for $B$. The value $P<0.05$ was considered statistically significant. Statistical analysis was done using SPSS 17.0 statistical software (SPSS Inc., Chicago, IL, USA).

\section{Results}

3.1. The Characteristics of the Subjects. The characteristics of the 56 nondialysis CKD patients with or without diabetes are shown in Table 1 . The CKD patients with diabetes had significantly lower serum albumin $(P=0.046)$ and lower serum magnesium $(P=0.023)$ and osteoporosis $(P=0.016)$ when compared to those CKD patients without diabetes. In addition, age, gender, eGFR, and CKD stages were not significantly different between CKD patients with diabetes and without diabetes.

3.2. Relationships of Serum $\mathrm{Mg}$ with Renal Function and Bone Metabolism Parameters in CKD Patients with or without Diabetes. As shown in Table 2, after adjusting for confounding factors, serum $\mathrm{Mg}$ was inversely correlated with serum $\mathrm{Ca}$ $(P=0.015)$ and positively correlated with serum iPTH $(P=0.041)$ and ALP $(P=0.027)$ in the CKD patients with diabetes. Moreover, serum $\mathrm{Mg}$ was inversely correlated with eGFR $(P=0.014)$ and positively correlated with creatinine $(P=0.007)$ and BUN $(P=0.044)$ in the CKD patients with diabetes. However, serum $\mathrm{Mg}$ was not significantly associated with serum $\mathrm{P}, 25(\mathrm{OH}) \mathrm{D}$, and $1,25(\mathrm{OH})_{2} \mathrm{D}$ in the CKD patients with diabetes. For CKD patients without diabetes, serum $\mathrm{Mg}$ showed an inverse correlation with $25(\mathrm{OH}) \mathrm{D}(P=0.006)$.
Moreover, serum $\mathrm{Mg}$ showed a positive correlation with serum creatinine $(P=0.040)$ and an inverse correlation with eGFR $(P=0.034)$ in the CKD patients without diabetes. There was a marginal inverse correlation between serum $\mathrm{Mg}$ and serum $\mathrm{Ca}$ in the $\mathrm{CKD}$ patients without diabetes $(P=$ 0.065). However, serum $\mathrm{Mg}$ had no significant correlation with serum urea nitrogen, $\mathrm{P}$, iPTH, ALP, and $1,25(\mathrm{OH})_{2} \mathrm{D}$ in the CKD patients without diabetes. On the other hand, $\mathrm{PTH}$ was inversely correlated with serum $\mathrm{Ca}(P=0.003)$ and 25(OH)D $(P=0.023)$ and positively correlated with serum $\operatorname{ALP}(P=0.005)$ and in the CKD patients with diabetes. However, iPTH was not significantly correlated with bone metabolism parameters in CKD patients without diabetes. In addition, iPTH also was not significantly correlated with renal function indicators in the CKD patients with or without diabetes.

3.3. Correlation of Different Serum Mg Levels with Renal Function and Bone Metabolism Parameters. The correlation of different serum $\mathrm{Mg}$ levels and bone metabolism parameters is shown in Table 3 and Figure 1. Although serum $\mathrm{Mg}$ levels were not statistically significantly correlated with osteoporosis, the low serum Mg subgroup presented a higher proportion of osteoporosis than that of moderate and high serum Mg subgroups (66.7\%, 39.4\%, and 29.4\%, resp.). Furthermore, the low serum Mg subgroup had a lower serum iPTH when compared with the moderate or high serum $\mathrm{Mg}$ subgroup. In contrast, the high serum $\mathrm{Mg}$ subgroup had a higher iPTH $(P=0.007)$, lower serum Ca $(P=0.018)$, elevated serum $\mathrm{P}(P=0.026)$, and lower serum $\mathrm{Ca} / \mathrm{Mg}$ 
TABLE 2: Relationships between serum Mg with renal function and bone metabolism parameters in CKD patients with or without diabetes.

\begin{tabular}{|c|c|c|c|c|c|c|c|c|}
\hline \multirow{2}{*}{ Dependent variables } & \multicolumn{4}{|c|}{$\log$ serum $\mathrm{Mg}(\mathrm{mg} / \mathrm{dL})$} & \multicolumn{4}{|c|}{$\log \mathrm{iPTH}(\mathrm{pg} / \mathrm{mL})$} \\
\hline & $B$ & $\beta$ & $P$ & $95 \%$ CI for $B$ & $B$ & $\beta$ & $P$ & $95 \% \mathrm{CI}$ for $B$ \\
\hline \multicolumn{9}{|l|}{ With diabetes } \\
\hline \multicolumn{9}{|l|}{ Renal function indicators $^{\dagger}$} \\
\hline $\log$ eGFR $(\mathrm{mL} / \mathrm{min})$ & -1.616 & -0.473 & 0.014 & $(-2.869,-0.363)$ & -0.191 & -0.282 & 0.220 & $(-0.504,0.122)$ \\
\hline log creatinine $(\mathrm{mg} / \mathrm{dL})$ & 1.539 & 0.528 & 0.007 & $(0.461,2.616)$ & 0.175 & 0.175 & 0.202 & $(-0.101,0.451)$ \\
\hline $\log \mathrm{BUN}(\mathrm{mg} / \mathrm{dL})$ & 0.952 & 0.391 & 0.044 & $(0.026,1.878)$ & 0.027 & 0.056 & 0.810 & $(-0.202,0.255)$ \\
\hline \multicolumn{9}{|l|}{ Bone metabolism parameters ${ }^{\ddagger}$} \\
\hline $\log \mathrm{iPTH}(\mathrm{pg} / \mathrm{mL})$ & 2.296 & 0.454 & 0.041 & $(0.109,4.483)$ & & & & \\
\hline $\log \mathrm{Ca}(\mathrm{mg} / \mathrm{dL})$ & -0.134 & -0.546 & 0.015 & $(-0.239,-0.028)$ & -0.030 & -0.626 & 0.003 & $(-0.049,-0.012)$ \\
\hline $\log \mathrm{P}(\mathrm{mg} / \mathrm{dL})$ & 0.272 & 0.312 & 0.106 & $(-0.063,0.608)$ & 0.040 & 0.231 & 0.222 & $(-0.026,0.106)$ \\
\hline $\log \operatorname{ALP}(\mathrm{U} / \mathrm{L})$ & 0.719 & 0.449 & 0.027 & $(0.093,1.345)$ & 0.168 & 0.529 & 0.005 & $(0.056,0.279)$ \\
\hline $\log 25(\mathrm{OH}) \mathrm{D}(\mathrm{ng} / \mathrm{mL})$ & -0.369 & -0.221 & 0.420 & $(-1.305,0.567)$ & -0.188 & -0.570 & 0.023 & $(-0.348,-0.029)$ \\
\hline $\log 1,25(\mathrm{OH})_{2} \mathrm{D}(\mathrm{pg} / \mathrm{mL})$ & -0.286 & -0.081 & 0.745 & $(-2.094,1.523)$ & -0.077 & -0.110 & 0.649 & $(-0.422,0.269)$ \\
\hline \multicolumn{9}{|l|}{ Without diabetes } \\
\hline \multicolumn{9}{|l|}{ Renal function indicators ${ }^{\dagger}$} \\
\hline $\log$ eGFR $(\mathrm{mL} / \mathrm{min})$ & -1.091 & -0.381 & 0.034 & $(-2.092,-0.090)$ & 0.040 & 0.084 & 0.665 & $(-0.150,0.231)$ \\
\hline log creatinine $(\mathrm{mg} / \mathrm{dL})$ & 0.922 & 0.404 & 0.040 & $(0.046,1.798)$ & -0.045 & -0.119 & 0.577 & $(-0.210,0.120)$ \\
\hline $\log \mathrm{BUN}(\mathrm{mg} / \mathrm{dL})$ & 0.426 & 0.172 & 0.368 & $(-0.531,1.382)$ & -0.020 & -0.047 & 0.814 & $(0.814,0.149)$ \\
\hline \multicolumn{9}{|l|}{ Bone metabolism parameters ${ }^{\ddagger}$} \\
\hline $\log \mathrm{iPTH}(\mathrm{pg} / \mathrm{mL})$ & 1.057 & 0.176 & 0.413 & $(-1.566,3.679)$ & & & & \\
\hline $\log \mathrm{Ca}(\mathrm{mg} / \mathrm{dL})$ & -0.153 & -0.407 & 0.068 & $(-0.318,0.012)$ & 0.007 & 0.118 & 0.597 & $(-0.021,0.026)$ \\
\hline $\log \mathrm{P}(\mathrm{mg} / \mathrm{dL})$ & 0.148 & -0.135 & 0.508 & $(-0.605,0.308)$ & -0.065 & -0.355 & 0.065 & $(-0.134,-0.004)$ \\
\hline $\log \operatorname{ALP}(\mathrm{U} / \mathrm{L})$ & 0.221 & 0.155 & 0.469 & $(-0.400,0.841)$ & 0.085 & 0.357 & 0.078 & $(-0.010,0.179)$ \\
\hline $\log 25(\mathrm{OH}) \mathrm{D}(\mathrm{ng} / \mathrm{mL})$ & -1.250 & -0.580 & 0.002 & $(-1.993,-0.507)$ & -0.079 & -0.219 & 0.273 & $(-0.223,0.066)$ \\
\hline $\log 1,25(\mathrm{OH})_{2} \mathrm{D}(\mathrm{pg} / \mathrm{mL})$ & 0.895 & 0.255 & 0.245 & $(-0.656,2.446)$ & 0.107 & 0.183 & 0.392 & $(-0.147,0.362)$ \\
\hline
\end{tabular}

(1) eGFR, estimated glomerular filtration rate; BUN, blood urine nitrogen; iPTH, intact parathyroid hormone; ALP, alkaline phosphatase; 25(OH)D, 25hydroxyvitamin $\mathrm{D} ; 1,25(\mathrm{OH})_{2} \mathrm{D}, 1,25$-dihydroxyvitamin $\mathrm{D}$.

(2) All outcomes of the multiple regression analysis are presented in unstandardized coefficients $(B)$ and standardized coefficients $(\beta)$ and at a $95 \%$ confidence interval (CI) for $B$. A $P$ value less than 0.05 was considered statistically significant. ${ }^{\dagger}$ Adjusted gender and age. ${ }^{\ddagger}$ Adjusted gender, age, albumin, and eGFR.

TABLE 3: Correlation of different serum Mg levels with osteoporosis and bone metabolism parameters.

\begin{tabular}{|c|c|c|c|c|}
\hline \multirow{2}{*}{ Variables } & \multicolumn{3}{|c|}{ Serum $\mathrm{Mg}(\mathrm{mg} / \mathrm{dL})$} & \multirow{2}{*}{$P$} \\
\hline & $<1.82(n=6)$ & $1.82-2.31(n=33)$ & $>2.31(n=17)$ & \\
\hline \multicolumn{5}{|l|}{ Osteoporosis } \\
\hline With & $4(66.7)$ & $13(39.4)$ & $5(29.4)$ & 0.314 \\
\hline Without & $2(33.3)$ & $20(60.6)$ & $12(70.6)$ & \\
\hline \multicolumn{5}{|c|}{ Bone metabolism parameters } \\
\hline iPTH (pg/mL) & $32.2(20.0-62.4)$ & $86.4(45.9-133.0)$ & $126.0(80.8-221.5)$ & 0.007 \\
\hline Serum Ca (mg/dL) & $9.0(8.7-9.5)$ & $8.9(8.6-9.3)$ & $8.7(8.2-8.9)$ & 0.018 \\
\hline Serum P (mg/dL) & $3.5(3.1-4.1)$ & $3.9(3.4-4.1)$ & $4.4(3.7-5.0)$ & 0.026 \\
\hline ALK-P (U/L) & $88.5(74.3-102.4)$ & $79.0(66.5-89.8)$ & $87.0(79.0-116.5)$ & 0.061 \\
\hline $25(\mathrm{OH}) \mathrm{D}(\mathrm{ng} / \mathrm{mL})$ & $27.2(17.7-37.3)$ & $22.7(18.5-28.0)$ & $23.6(14.6-28.0)$ & 0.631 \\
\hline $1,25(\mathrm{OH})_{2} \mathrm{D}(\mathrm{pg} / \mathrm{mL})$ & $24.0(15.5-29.4)$ & $16.6(11.9-31.2)$ & $15.4(11.8-23.9)$ & 0.516 \\
\hline Serum $\mathrm{Ca} / \mathrm{Mg}$ ratio & $5.1(5.0-5.6)$ & $4.1(3.8-4.4)$ & $3.4(2.8-3.6)$ & $<0.001$ \\
\hline Serum $\mathrm{Ca} \times \mathrm{P}$ value & $31.2(27.8-38.1)$ & $33.8(29.5-38.3)$ & $37.4(34.6-41.9)$ & 0.128 \\
\hline
\end{tabular}

(1) iPTH, intact parathyroid hormone; ALP, alkaline phosphatase; 25(OH)D, 25-hydroxyvitamin $\mathrm{D} ; 1,25(\mathrm{OH})_{2} \mathrm{D}, 1,25$-dihydroxyvitamin $\mathrm{D}$.

(2) Comparisons of continuous data between three groups were analyzed by Kruskal Wallis test. Data are median and range (25th pctl-75th pctl).

(3) Comparisons of categorical data between two groups were analyzed by Chi-square test. When cells have expected count less than 5 , data were analyzed by Fisher's Exact test. Data are number $(n)$, percent $(\%)$.

(4) A $P$ value less than 0.05 was considered statistically significant. 


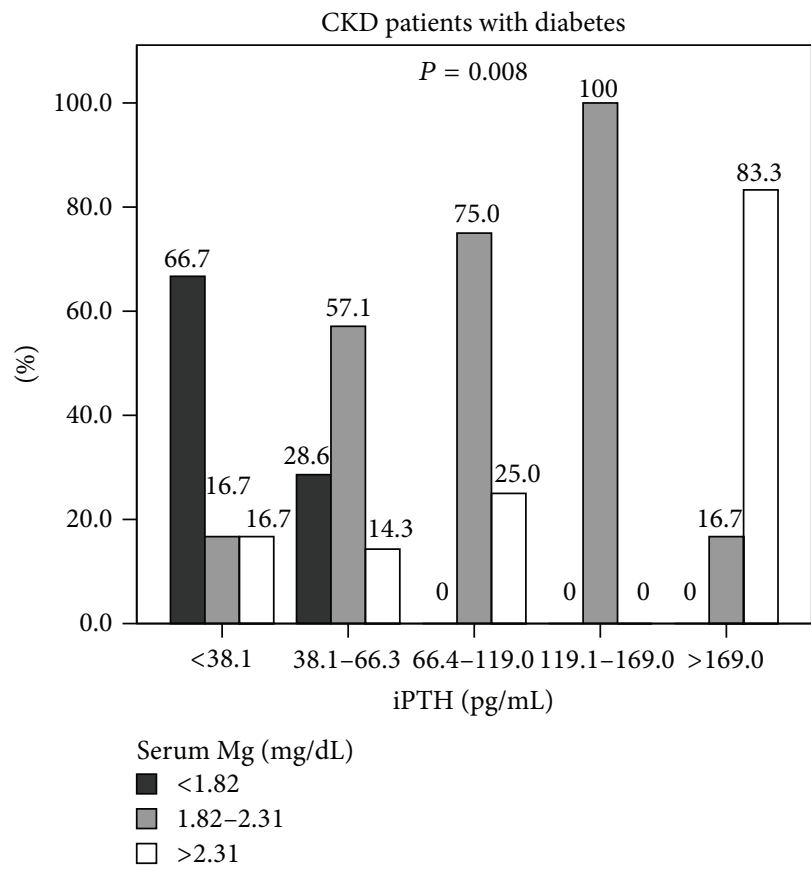

(a)

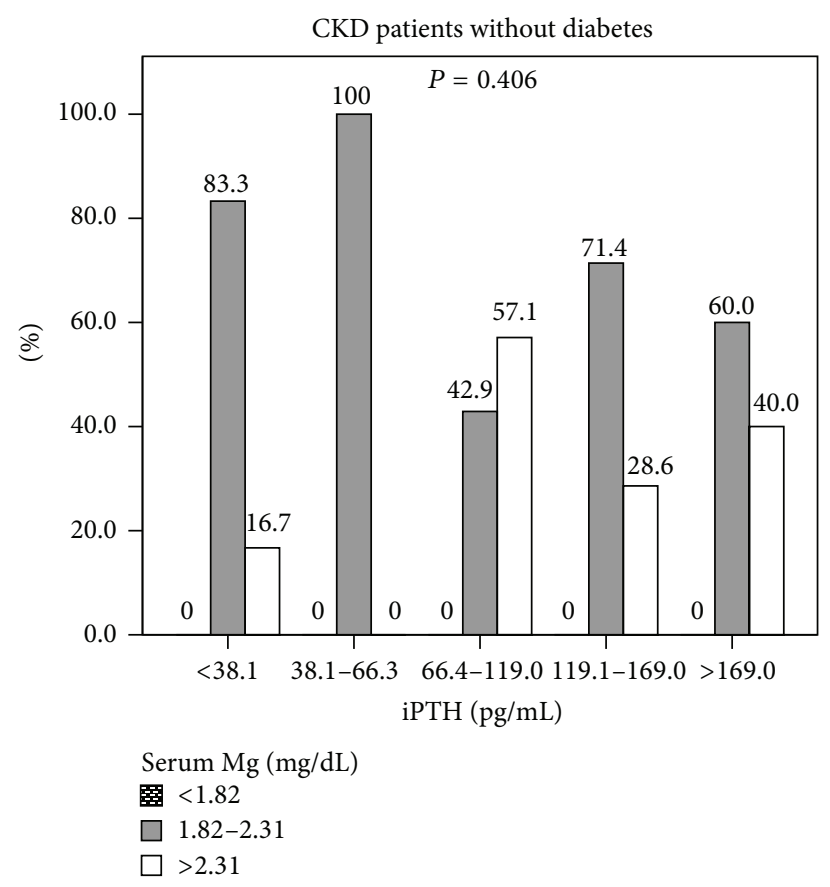

(b)

FIgURE 1: Correlation between serum Mg levels and iPTH levels. (a) CKD patients with diabetes. (b) CKD patients without diabetes. Comparisons of categorical data between two groups were analyzed by Chi-square test. When cells have expected count less than 5, data were analyzed by Fisher's Exact test. Data are presented as percentage (\%). A $P$ value less than 0.05 was considered statistically significant.

ratio $(P<0.001)$ when compared with the moderate or low serum Mg subgroup. However, serum Mg levels were not significantly associated with serum $\mathrm{Ca} \times \mathrm{P}$ value, $25(\mathrm{OH}) \mathrm{D}$, and $1,25(\mathrm{OH})_{2} \mathrm{D}$. After stratifying the CKD patients based on presence or lack of diabetes, serum $\mathrm{Mg}$ levels were significantly correlated with iPTH levels in the CKD patients with diabetes $(P=0.008)$ but not in those without diabetes (Figure 1). Moreover, among six diabetic CKD patients with hypomagnesemia, four patients had low iPTH levels and four patients had osteoporosis.

3.4. Bone Metabolic Parameter Levels for the CKD Patients with Osteoporosis by Low and High Serum Mg Levels. As shown in Table 4, of six diabetic CKD patients with hypomagnesemia, four patients had low iPTH levels (range of 7.8$38.1 \mathrm{pg} / \mathrm{mL}$ ), four patients had osteoporosis, and one patient had osteopenia. Three patients had 25(OH)D insufficiencydeficiency (range of $11.3-21.6 \mathrm{ng} / \mathrm{mL}$ ), and three patients had $1,25(\mathrm{OH})_{2} \mathrm{D}$ deficiency (range of 5.1-22.1 pg/mL). Of the five CKD patients with high serum $\mathrm{Mg}$ and osteoporosis, four patients had diabetes and one patient did not have diabetes. The nondiabetic CKD patient with high serum $\mathrm{Mg}$ and osteoporosis had high iPTH levels and low levels of serum $\mathrm{Ca}, 25(\mathrm{OH}) \mathrm{D}$, and $1,25(\mathrm{OH})_{2} \mathrm{D}$. Furthermore, of the four diabetic CKD patients with high serum $\mathrm{Mg}$ and osteoporosis, three patients had also high iPTH (range of 83.8-293.0 pg/mL), 25(OH)D insufficiency-deficiency (range of $13.2-23.8 \mathrm{pg} / \mathrm{mL}$ ), 1,25(OH) ${ }_{2} \mathrm{D}$ deficiency (range of 5.2$19.7 \mathrm{pg} / \mathrm{mL}$ ), and tendency to low serum Ca (range of 8.4$9.0 \mathrm{mg} / \mathrm{dL})$.
3.5. Relationships of PTH Levels with Serum $\mathrm{Ca}: \mathrm{Mg}$ Ratio and Serum $\mathrm{Ca} \times \mathrm{P}$ Value. The relationships of PTH levels with the serum $\mathrm{Ca} / \mathrm{Mg}$ ratio and serum $\mathrm{Ca} \times \mathrm{P}$ were analyzed via multivariate analysis using the General Linear Model, with sex, age, diabetes, and eGFR as the adjusted variables. Data are adjusted for mean and SE. The serum $\mathrm{Ca} / \mathrm{Mg}$ ratio of Q1 (<38.1), Q2 (38.1-66.3), Q3 (66.4-119.0), Q4 (119.1-169.0), and Q5 (>169.0), based on quintiles of PTH levels, was $4.5 \pm 0.2$, $4.0 \pm 0.2,3.7 \pm 0.2,4.2 \pm 0.2$, and $3.5 \pm 0.2$, respectively $(P=0.019)$. Following Bonferroni's post hoc comparisons, the Q5 group had a lower serum $\mathrm{Ca} / \mathrm{Mg}$ ratio than the Q1 group $(P<0.05)$. However, PTH levels were not associated with the serum $\mathrm{Ca} \times \mathrm{P}$ values $(P=0.483)$. In addition, linear regression analysis was performed to examine the impact of the serum $\mathrm{Ca} / \mathrm{Mg}$ ratio on the $\mathrm{PTH}$, also using sex, age, diabetes, and eGFR as adjusted variables. Our data indicated that the serum $\mathrm{Ca} / \mathrm{Mg}$ ratio was inversely correlated with PTH levels $(P=0.027)$ and $B$ was -1.455 , whereas $\beta$ was -0.305 , and the $95.0 \%$ confidence interval for $B$ was -2.740 to -0.170 . However, PTH levels were not correlated with the serum $\mathrm{Ca} \times \mathrm{P}$ values $(P=0.182)$.

\section{Discussion}

Appropriate management of abnormal bone mineral metabolism may reduce CKD patients' risk of developing some complications [26]. The aim of the present study is to investigate the impacts of serum $\mathrm{Mg}$ levels on bone mineral metabolism in the CKD patients with and without diabetes. Our findings show that the hypomagnesemia may 
TABLE 4: Bone metabolic parameters levels for the CKD patients with osteoporosis by low and high serum Mg levels.

\begin{tabular}{|c|c|c|c|c|c|c|c|}
\hline Case & CKD stage & iPTH (pg/mL) & $\mathrm{Ca}(\mathrm{mg} / \mathrm{dL})$ & $\mathrm{P}(\mathrm{mg} / \mathrm{dL})$ & $25(\mathrm{OH}) \mathrm{D}(\mathrm{ng} / \mathrm{mL})$ & $1,25(\mathrm{OH})_{2} \mathrm{D}(\mathrm{pg} / \mathrm{mL})$ & Bone health status \\
\hline \multicolumn{8}{|c|}{ Low serum $\mathrm{Mg}$} \\
\hline \multicolumn{8}{|c|}{ Diabetes } \\
\hline 1 & 3 & 61.3 & 9.0 & 3.1 & 21.6 & 22.1 & Osteoporosis \\
\hline 2 & 3 & 26.2 & 9.4 & 3.3 & 37.8 & 25.9 & Osteoporosis \\
\hline 3 & 4 & 7.8 & 9.0 & 3.1 & 37.1 & 35.2 & Osteoporosis \\
\hline 4 & 5 & 38.1 & 8.6 & 4.4 & 19.9 & 27.4 & Osteoporosis \\
\hline 5 & 4 & 24.1 & 9.7 & 4.1 & 32.8 & 19 & Osteopenia \\
\hline 6 & 3 & 65.8 & 8.7 & 3.6 & 11.3 & 5.1 & Normal \\
\hline \multicolumn{8}{|c|}{ High serum $M g$} \\
\hline \multicolumn{8}{|c|}{ Diabetes } \\
\hline 1 & 3 & 51.5 & 8.7 & 3.6 & 23.8 & 26.8 & Osteoporosis \\
\hline 2 & 4 & 83.8 & 9.0 & 3.9 & 13.2 & 15.9 & Osteoporosis \\
\hline 3 & 5 & 184.0 & 8.4 & 5.9 & 25.1 & 19.7 & Osteoporosis \\
\hline 4 & 5 & 293.0 & 8.7 & 4.7 & 15.9 & 5.2 & Osteoporosis \\
\hline \multicolumn{8}{|c|}{ Nondiabetes } \\
\hline 1 & 5 & 169.0 & 8.7 & 4.2 & 17.8 & 3.4 & Osteoporosis \\
\hline
\end{tabular}

(1) For patients with stages 3, 4, and $5 \mathrm{CKD}$, PTH is in the range of 35-70 pg/mL, 70-110 pg/mL, and 150-300 pg/mL, respectively.

(2) For patients with stages 3 to 4 CKD, serum Ca should be maintained within normal range, $8.9-10.1 \mathrm{mg} / \mathrm{dL}$, and serum P should be within $2.7-4.6 \mathrm{mg} / \mathrm{dL}$. For patients with stage 5 CKD, serum Ca should be $8.4-9.5 \mathrm{mg} / \mathrm{dL}$ and serum $\mathrm{P}$ target should be $3.3-5.5 \mathrm{mg} / \mathrm{dL}$.

(3) Vitamin D deficiency is defined as a serum $25(\mathrm{OH}) \mathrm{D}$ level of less than $20 \mathrm{ng} / \mathrm{mL}$ and vitamin $\mathrm{D}$ insufficiency is defined as a serum $25(\mathrm{OH}) \mathrm{D}$ level of 20 to $30 \mathrm{ng} / \mathrm{mL}$. Serum $1,25(\mathrm{OH})_{2}$ D deficiency is defined as a serum $1,25(\mathrm{OH})_{2} \mathrm{D}$ level of less than $25.1 \mathrm{ng} / \mathrm{mL}$.

cause low iPTH levels and may aggravate bone mineral disorders in CKD patients with diabetes. Serum Mg levels were inversely correlated with serum Ca levels and positively correlated with iPTH, ALP, and P levels in the CKD patients with diabetes. Moreover, the CKD patients with diabetes had lower serum albumin and a higher proportion of hypomagnesemia and osteoporosis. In addition, serum $\mathrm{Mg}$ levels were inversely correlated with eGFR and positively correlated with serum creatinine levels in the CKD patients with or without diabetes. Serum $\mathrm{Mg}$ showed an inverse correlation with $25(\mathrm{OH}) \mathrm{D}$ in CKD patients without diabetes. Furthermore, serum $\mathrm{Ca} / \mathrm{Mg}$ ratios were inversely correlated with the PTH levels.

4.1. Serum Mg and Osteoporosis in the CKD Patients with or without Diabetes. In the present study, CKD patients with diabetes had lower serum albumin and a higher proportion of hypomagnesemia and osteoporosis than those of CKD patients without diabetes. The possible explanation for this is that diabetic nephropathy is characterized by decreased renal function and significant albuminuria [30]. Serum albumin acts as a transport protein for numerous substances, including $\mathrm{Mg}, \mathrm{Ca}$, and zinc [31]. Therefore, the amount of total $\mathrm{Mg}$ and $\mathrm{Ca}$ may lower with the albumin decreasing in CKD patients with diabetes. Indeed, our data was consistent with findings from other studies $[13,32,33]$. A retrospective cohort study reported that the subjects with low serum $\mathrm{Mg}$ had higher proteinuria and lower serum albumin levels among CKD patients with or without diabetes. In particular, CKD patients with diabetes had more serious proteinuria and low levels of serum albumin and $\mathrm{Mg}$ than those of nondiabetic CKD patients [13]. Dewitte et al. also reported that renal failure patients with diabetes had lower blood $\mathrm{Mg}$ levels than nondiabetic patients [32]. Furthermore, hypomagnesemia is common in patients with diabetes [33], and it is associated with osteoporosis [6]. Our findings suggest that CKD patients with diabetes had lower serum albumin and a higher proportion of hypomagnesemia, and this may be related to the development of osteoporosis.

4.2. Serum Mg and Bone Mineral Metabolism. The differences in the relationship between serum $\mathrm{Mg}$ levels with bone mineral metabolism among CKD patients with and without diabetes are still under controversy. Our findings showed that serum Mg levels were positively correlated with iPTH and inversely correlated with serum $\mathrm{Ca}$ and $25(\mathrm{OH}) \mathrm{D}$ before stratifying the CKD patients depending on whether or not they had diabetes. After stratifying the CKD patients based on presence or absence of diabetes, there remains an inverse correlation between serum $\mathrm{Mg}$ and $25(\mathrm{OH}) \mathrm{D}$ in $\mathrm{CKD}$ patients without diabetes. Nevertheless, serum $\mathrm{Mg}$ levels were inversely correlated with serum $\mathrm{Ca}$ levels and positively correlated with iPTH and ALP in the CKD patients with diabetes but not in those without diabetes. Recently, Kanbay et al. reviewed the literature and concluded that serum $\mathrm{Mg}$ is inversely correlated with PTH in the general population [34]. Sakaguchi et al. reported that serum $\mathrm{Mg}$ levels had no correlation with serum Ca levels in $\mathrm{CKD}$ patients. Conversely, serum $\mathrm{Mg}$ levels were positively correlated with P levels [13]. Navarro et al. discovered that hypermagnesemia is common in peritoneal dialysis patients, and there was an inverse correlation between serum $\mathrm{Mg}$ and PTH [35]. Furthermore, the relationships of serum Mg with PTH and mineral metabolism have yielded conflicting 
data in hemodialysis (HD) patients. An inverse correlation between $\mathrm{Mg}$ levels and PTH in HD patients was claimed in some studies [36, 37]. However, another study showed that serum Mg levels positively correlated with plasma $\mathrm{P}$, but no correlations between serum $\mathrm{Mg}$ and serum $\mathrm{Ca}$ or $\mathrm{PTH}$ in HD patients were found [38]. Our findings and data from other studies indicated that serum $\mathrm{Mg}$ levels may play an important role in regulating the $\mathrm{PTH}$ levels and bone mineral metabolism in CKD patients [13, 35]. However, relationship between serum $\mathrm{Mg}$ with PTH and bone mineral metabolism may vary with the presence of diabetes and different renal replacement therapies. Therefore, the effect of serum $\mathrm{Mg}$ levels on PTH and bone mineral metabolism in CKD patients needs further exploration.

\subsection{Low Serum Mg Levels, Low iPTH Levels, and Osteoporosis.} The most commonly encountered types of bone disease in CKD are lower turnover bone disease (adynamic bone disease), high-turnover bone disease (bone resorption), and mixed bone disease [26]. We further focus on the impacts of low or high serum Mg levels on PTH and bone mineral metabolism in CKD patients. Our data showed that serum $\mathrm{Mg}$ levels were correlated with iPTH levels in the CKD patients with diabetes. The subgroup with low serum $\mathrm{Mg}$ levels had lower iPTH levels and higher serum $\mathrm{Ca} / \mathrm{Mg}$ ratios when compared with the moderate or high serum Mg levels subgroup. Moreover, our data showed six patients found hypomagnesemia in the CKD with diabetes patients but not in non-diabetes patients. Of six diabetic CKD patients with hypomagnesemia, four patients had low iPTH levels, four patients had osteoporosis, and one patient had osteopenia. Three patients had 25(OH)D insufficiency-deficiency, and three patients had $1,25(\mathrm{OH})_{2} \mathrm{D}$ deficiency. Indeed, hypomagnesemia affects the secretion and activity of PTH as well as tissue sensitivity to PTH $[39,40]$ and reduces the activity of the 25-hydroxycholecalciferol-1-hydroxylase, hence resulting in low serum concentrations of $1,25(\mathrm{OH})_{2} \mathrm{D}[2,24]$. Therefore, these diabetic CKD patients with low iPTH levels and osteoporosis may belong to lower turnover bone disease (adynamic bone disease) [26], and the low serum Mg may be a major cause. A cross-sectional study also has shown that type 2 diabetes patients have lower levels of bone resorption markers and PTH compared with subjects without diabetes [41]. Yamamoto et al. indicated that decreased PTH levels accompanied by low bone formation are related to vertebral fractures in postmenopausal women with type 2 diabetes. Therefore, lower levels of PTH may induce a lower turnover state, and this status may be correlated with the higher risk of fracture in patients with diabetes [22]. Our findings suggest that low serum $\mathrm{Mg}$ levels may cause insufficient PTH action, and this may eventually cause lower turnover bone disease in CKD patients with diabetes.

4.4. High Serum Mg, High PTH, and Osteoporosis. In contrast, our findings showed that the subgroup with high serum $\mathrm{Mg}$ had a higher iPTH, lower serum $\mathrm{Ca}$, elevated serum $\mathrm{P}$, and lower serum $\mathrm{Ca}: \mathrm{Mg}$ ratio when compared with the moderate or low serum $\mathrm{Mg}$ subgroup. Of the five CKD patients with high serum $\mathrm{Mg}$ and osteoporosis, four patients have diabetes and one patient has no diabetes. The nondiabetic CKD patient with high serum $\mathrm{Mg}$ and osteoporosis had high iPTH levels and low levels of serum $\mathrm{Ca}, 25(\mathrm{OH}) \mathrm{D}$, and $1,25(\mathrm{OH})_{2} \mathrm{D}$. In addition, of the four diabetic CKD patients with high serum $\mathrm{Mg}$ and osteoporosis, three patients also had high iPTH, 25(OH)D insufficiencydeficiency, $1,25(\mathrm{OH})_{2} \mathrm{D}$ deficiency, and a low serum $\mathrm{Ca}$ trend. These CKD patients with high serum Mg levels, raised PTH levels, vitamin D deficiency, low Ca levels, and osteoporosis may be considered as having a high-turnover bone disease (bone resorption) [26]. Although high serum $\mathrm{Mg}$ levels may inhibit PTH secretion [6], Mg is able to reduce PTH secretion mainly when moderate to low Ca levels are present [40]. Moreover, the stimulus to produce PTH by low serum Ca levels may be more strongly influenced, rather than inhibited, by the effect of high serum $\mathrm{Mg}$ levels on PTH secretion [42]. Furthermore, elevated PTH levels can lead to increased bone resorption [26]. Hypermagnesemia may also cause complications in CKD patients [6]. Our data suggests that high serum Mg levels may no longer be enough to suppress PTH secretion when moderate-severe CKD patients with low serum Ca levels do not receive dialysis. Patients who maintain $\mathrm{Ca}$ levels within the normal range and avoid excess $\mathrm{P}$ and $\mathrm{Mg}$ levels may be key points for clinical care.

4.5. Serum $\mathrm{Ca} / \mathrm{Mg}$ Ratio and PTH Levels. Recently, more and more studies are paying attention to the importance of $\mathrm{Ca}$ and $\mathrm{Mg}$ balance on preventing disease [43-45]. An inadequate $\mathrm{Ca} / \mathrm{Mg}$ ratio may cause inflammation, cardiovascular disease, and cancer $[44,45]$. However, impacts of $\mathrm{Ca} / \mathrm{Mg}$ ratio on bone mineral metabolism have not been fully investigated. Our data and several studies have shown that serum Mg level was associated with serum PTH and Ca levels. Moreover, varied serum $\mathrm{Mg}$ and Ca levels may affect the suppression or production of PTH levels $[6,40,42]$. Therefore, interactions between serum $\mathrm{Mg}$ and $\mathrm{Ca}$ or the serum $\mathrm{Ca} / \mathrm{Mg}$ ratio may be an important factor in the modulation of PTH levels and reducing the development of bone mineral disease. In the present study, we further analyze the relationship between PTH levels with serum $\mathrm{Ca} / \mathrm{Mg}$ ratio and serum $\mathrm{Ca} \times \mathrm{P}$ values in CKD patients. Our findings showed that the serum $\mathrm{Ca} / \mathrm{Mg}$ ratio was inversely correlated with the $\mathrm{PTH}$ levels. However, PTH levels were not associated with the serum Ca $\times \mathrm{P}$ values. The CKD patients with low PTH levels had higher serum $\mathrm{Ca} / \mathrm{Mg}$ ratios of 4.5 than those of other subgroups. In contrast, the CKD patients with high PTH levels had lower serum $\mathrm{Ca} / \mathrm{Mg}$ ratios of 3.5 than those of other subgroups. In addition, CKD patients with low serum $\mathrm{Mg}$ and low $\mathrm{PTH}$ indeed had higher serum $\mathrm{Ca} / \mathrm{Mg}$ ratio of 5.1. The $\mathrm{CKD}$ patients with high serum $\mathrm{Mg}$, elevated PTH, and low serum $\mathrm{Ca}$ had lower serum $\mathrm{Ca} / \mathrm{Mg}$ ratios of 3.4 (Table 3 ). Thus, we are speculating that serum $\mathrm{Ca} / \mathrm{Mg}$ ratios greater than 4.5 may cause insufficient parathyroid hormone action and deteriorate lower turnover bone diseases in CKD patients. In contrast, serum $\mathrm{Ca} / \mathrm{Mg}$ ratios less than 3.5 may cause stimulation to produce PTH and lead to high-turnover bone diseases in CKD patients. Our data suggest that the serum $\mathrm{Ca} / \mathrm{Mg}$ ratio may be a novel determinant of $\mathrm{PTH}$ level, and this may be correlated with lower or high-turnover status 
in CKD patients. Future research shall pay much attention to the effects of serum $\mathrm{Ca} / \mathrm{Mg}$ ratios on $\mathrm{PTH}$ levels and bone mineral metabolism as well as what the adequate serum $\mathrm{Ca} / \mathrm{Mg}$ ratios in moderate-severe CKD patients are.

4.6. Serum $M g$ and Renal Functional Declines. In a recent study, serum Mg levels were inversely correlated with eGFR and positively correlated with serum creatinine levels in the CKD patients with and without diabetes. Our finding in CKD patients without diabetes was consistent with that of Sakaguchi et al., who reported that serum $\mathrm{Mg}$ levels had a negative correlation with creatinine clearance in patients without type 2 diabetes [13]. Dewitte et al. also found that serum Mg levels increase when creatinine clearance from 115 falls to $30 \mathrm{~mL} / \mathrm{min}$ in renal failure patients without diabetes [32]. Conversely, serum Mg levels were not correlated with renal functional parameters including creatinine and GFR in the diabetic patients $[13,32]$. Nevertheless, even if CKD patients with diabetes had higher proteinuria levels and lower serum $\mathrm{Mg}$ levels than those of nondiabetic CKD patients $[13,32]$, the serum $\mathrm{Mg}$ levels may rise when renal functional declines to moderate-severity CKD patients [12]. As the GFR falls below $30 \mathrm{~mL} / \mathrm{min}$, urinary $\mathrm{Mg}$ excretion may be insufficient to balance the intestinal $\mathrm{Mg}$ absorption [12]. Thus, the CKD patient with diabetes may be similar to the CKD patient without diabetes when declining renal function was accompanied by increases in serum $\mathrm{Mg}$ levels. Our data suggested that there is an inverse correlation between serum $\mathrm{Mg}$ levels with eGFR in the CKD patients with and without diabetes. Therefore, the dietary Mg intake should be a major determinant of serum $\mathrm{Mg}$ levels when the serum $\mathrm{Mg}$ level is raised with renal functional declines.

4.7. Policy Implications for Medical Care. In general, CKD disrupts $\mathrm{Ca}$ and $\mathrm{P}$ homeostasis and causes alterations of PTH and vitamin D levels [9-11]. These alterations may lead to complications, including bone and mineral metabolic diseases [9-11]. Nevertheless, the importance of $\mathrm{Mg}$ imbalance in disorders of bone mineral metabolism has been neglected in the clinical management of patients with CKD. The major findings of our study may have guideline implications for medical care in CKD patients, with and without diabetes. Our findings suggest that low serum Mg levels may cause insufficient parathyroid hormone action and may further lead to bone diseases in CKD patients with diabetes. For these patients, adequate $\mathrm{Mg}$ intake by diet or supplement may reduce the development of lower turnover bone disease. In contrast, the inhibitory effect of a high serum $\mathrm{Mg}$ level on PTH secretion may be offset by the stimulation produced through low serum $\mathrm{Ca}$ in moderate-severe CKD patients, who are not receiving dialysis. We suggest that these patients maintain a serum $\mathrm{Ca}$ level within the optimal range and avoid consuming excess amounts of $\mathrm{Mg}$ and $\mathrm{P}$ to reduce the risk of high-turnover bone diseases. Moreover, there should be routine monitoring of serum $\mathrm{Mg}$ levels, and paying attention to the balance of serum $\mathrm{Ca}$ and $\mathrm{Mg}$ is important in the assessment and management of bone mineral disorders in CKD patients with or without diabetes.
4.8. Limitations. Our study has several limitations. First of all, the most major one is the relatively small sample size, which may decrease the power of statistical analysis among subgroups. Inadequate statistical power may provide only pilot results for data analysis. Secondly, the generalizability of the results may be limited because the patients were residents in a rural area. Thirdly, the cross-sectional design may not conclude $\mathrm{Mg}$ deficiency as a cause of insufficient parathyroid hormone action in CKD patients with diabetes. Despite these limitations, our findings provide important implications for moderate-severe CKD patients. Our findings showed that low serum Mg levels may impact PTH levels and deteriorate osteoporosis. These data are inconsistent with those reported by several previous studies $[2,39]$. The present data may also be applicable to nonrural CKD patients with low Mg and PTH levels. Thus, clinical staff may educate these patients with nutrition knowledge of increasing dietary $\mathrm{Mg}$ intakes from food or $\mathrm{Mg}$ supplements. They may improve the low Mg status, modulate secretion and activity of the $\mathrm{PTH}$, and reduce the risk of developing osteoporosis. Further prospectively designed and supplementary studies with a large sample size may help us to reveal the effects of the $\mathrm{Mg}$ status on PTH and bone mineral metabolism in CKD patients with or without diabetes.

\section{Conclusions}

The CKD patients with diabetes have a higher prevalence of hypomagnesemia and osteoporosis. Low serum $\mathrm{Mg}$ may cause insufficient PTH action and deteriorate osteoporosis in CKD patients, particularly those with diabetes. Clinical care should focus on monitoring and managing the serum $\mathrm{Mg}$ levels to reduce the development of bone mineral disease in moderate-severe CKD patients who are not receiving dialysis, particularly, CKD patients with diabetes.

$\begin{array}{ll}\text { Abbreviations } \\ \text { ALP: } & \text { Alkaline phosphatase } \\ \text { BUN: } & \text { Blood urea nitrogen } \\ \text { Ca: } & \text { Calcium } \\ \text { CKD: } & \text { Chronic kidney disease } \\ \text { eGFR: } & \text { Estimated glomerular filtration rate } \\ \text { HD: } & \text { Hemodialysis } \\ \text { iPTH: } & \text { Intact parathyroid hormone } \\ \text { MDRD: } & \text { Modification of Diet in Renal Disease } \\ \text { Mg: } & \text { Magnesium } \\ \text { 1,25(OH })_{2} \text { D: } & 1,25-\text { Dihydroxyvitamin D } \\ 25(\mathrm{OH}) \mathrm{D}: & \text { 25-Hydroxyvitamin D. }\end{array}$

\section{Conflict of Interests}

The authors declare that they have no competing interests.

\section{Authors' Contribution}

Jui-Hua Huang participated in the design of study, implementation of study, and analysis and interpretation of data and initiated the first draft of the paper. Fu-Chou Cheng 
participated in the interpretation of the original data and in revision and editing of the final paper and initiated the first draft of paper,. Hsu-Chen Wu has substantial contributions to the conception and the original design of study, conducting the clinical study, and furnishing the final paper. All the authors have read and approved the final paper.

\section{Acknowledgments}

This study was supported by Erlin Community Investigation Project 93150 in Changhua Christian Hospital, Taiwan. The authors thank Dr. Jia-Zhen Lu and the medical staff at Erlin Branch Hospital for their enthusiastic supports. In addition, the authors thank technicians in the Department of Laboratory Medicine of Erlin Branch Hospital for analyzing all blood and urine samples in this study.

\section{References}

[1] N. E. Lane, "Epidemiology, etiology, and diagnosis of osteoporosis," American Journal of Obstetrics \& Gynecology, vol. 194, no. 2, supplement, pp. S3-S11, 2006.

[2] R. K. Rude, F. R. Singer, and H. E. Gruber, "Skeletal and hormonal effects of magnesium deficiency," Journal of the American College of Nutrition, vol. 28, no. 2, pp. 131-141, 2009.

[3] B. S. Levine, M. Rodriguez, and A. J. Felsenfeld, "Serum calcium and bone: effect of PTH, phosphate, vitamin D and uremia," Nefrologia, vol. 34, no. 5, pp. 658-669, 2014.

[4] D. Wlodarek, D. Glabska, A. Kolota, and et al, "Calcium intake and osteoporosis: the influence of calcium intake from dairy products on hip bone mineral density and fracture incidencea population-based study in women over 55 years of age," Public Health Nutrition, vol. 17, no. 2, pp. 383-389, 2014.

[5] K. Tomida, T. Hamano, S. Mikami et al., "Serum 25-hydroxyvitamin $\mathrm{D}$ as an independent determinant of 1-84 PTH and bone mineral density in non-diabetic predialysis CKD patients," Bone, vol. 44, no. 4, pp. 678-683, 2009.

[6] S. Castiglioni, A. Cazzaniga, W. Albisetti, and J. A. M. Maier, "Magnesium and osteoporosis: current state of knowledge and future research directions," Nutrients, vol. 5, no. 8, pp. 30223033, 2013.

[7] R. W. Gray, J. L. Omdahl, J. G. Ghazarian, and H. F. DeLuca, “25Hydroxycholecalciferol-1-hydroxylase. Subcellular location and properties," The Journal of Biological Chemistry, vol. 247, no. 23, pp. 7528-7532, 1972.

[8] H. Matsuzaki, S.-I. Katsumata, Y. Kajita, and M. Miwa, "Magnesium deficiency regulates vitamin D metabolizing enzymes and type II sodium-phosphate cotransporter mRNA expression in rats," Magnesium Research, vol. 26, no. 2, pp. 83-86, 2013.

[9] A. Stavroulopoulos, C. J. Porter, S. D. Roe, D. J. Hosking, and M. J. D. Cassidy, "Relationship between vitamin D status, parathyroid hormone levels and bone mineral density in patients with chronic kidney disease stages 3 and 4," Nephrology, vol. 13, no. 1, pp. 63-67, 2008.

[10] M. Rouached, S. El Kadiri Boutchich, A. M. Al Rifai, M. Garabédian, and A. Fournier, "Prevalence of abnormal serum vitamin D, PTH, calcium, and phosphorus in patients with chronic kidney disease: Results of the study to evaluate early kidney disease," Kidney International, vol. 74, no. 3, pp. 389-390, 2008.
[11] O. Moranne, M. Froissart, J. Rossert et al., "Timing of onset of CKD-related metabolic complications," Journal of the American Society of Nephrology, vol. 20, no. 1, pp. 164-171, 2009.

[12] J. F. Navarro-González, C. Mora-Fernández, and J. GarcíaPérez, "Clinical implications of disordered magnesium homeostasis in chronic renal failure and dialysis," Seminars in Dialysis, vol. 22, no. 1, pp. 37-44, 2009.

[13] Y. Sakaguchi, T. Shoji, T. Hayashi et al., "Hypomagnesemia in type 2 diabetic nephropathy: a novel predictor of end-stage renal disease," Diabetes Care, vol. 35, no. 7, pp. 1591-1597, 2012.

[14] J. M. Topf and P. T. Murray, "Hypomagnesemia and hypermagnesemia," Reviews in Endocrine \& Metabolic Disorders, vol. 4, no. 2, pp. 195-206, 2003.

[15] S. Okuno, "Magnesium disorder and its clinical significance in chronic kidney disease," Clinical Calcium, vol. 22, no. 8, pp. 1243-1249, 2012.

[16] J. G. Gums, "Magnesium in cardiovascular and other disorders," American Journal of Health-System Pharmacy, vol. 61, no. 15, pp. 1569-1576, 2004.

[17] A. Navarrete-Cortes, J. L. Ble-Castillo, F. Guerrero-Romero et al., "No effect of magnesium supplementation on metabolic control and insulin sensitivity in type 2 diabetic patients with normomagnesemia," Magnesium Research, vol. 27, no. 2, pp. 48$56,2014$.

[18] L. M. Giangregorio, W. D. Leslie, L. M. Lix et al., "FRAX underestimates fracture risk in patients with diabetes," Journal of Bone and Mineral Research, vol. 27, no. 2, pp. 301-308, 2012.

[19] P. Dousdampanis, K. Trigka, and C. Fourtounas, "Hypomagnesemia, chronic kidney disease and cardiovascular mortality: pronounced association but unproven causation," Hemodialysis International, vol. 18, no. 4, pp. 730-739, 2014.

[20] F. J. A. Paula, C. M. M. Lanna, T. Shuhama, and M. C. Foss, "Effect of metabolic control on parathyroid hormone secretion in diabetic patients," Brazilian Journal of Medical and Biological Research, vol. 34, no. 9, pp. 1139-1145, 2001.

[21] R. M. Yoho, J. Frerichs, N. B. Dodson, R. Greenhagan, and S. Geletta, "A comparison of vitamin D levels in nondiabetic and diabetic patient populations," Journal of the American Podiatric Medical Association, vol. 99, no. 1, pp. 35-41, 2009.

[22] M. Yamamoto, T. Yamaguchi, K. Nawata, M. Yamauchi, and T. Sugimoto, "Decreased PTH levels accompanied by low bone formation are associated with vertebral fractures in postmenopausal women with type 2 diabetes," The Journal of Clinical Endocrinology and Metabolism, vol. 97, no. 4, pp. 12771284, 2012.

[23] A. Dasgupta, D. Sarma, and U. K. Saikia, "Hypomagnesemia in type 2 diabetes mellitus," Indian Journal of Endocrinology and Metabolism, vol. 16, no. 6, pp. 1000-1003, 2012.

[24] R. K. Rude, J. S. Adams, E. Ryzen et al., "Low serum concentrations of 1,25-dihydroxyvitamin D in human magnesium deficiency," The Journal of Clinical Endocrinology \& Metabolism, vol. 61, no. 5, pp. 933-940, 1985.

[25] M. J. Arnaud, "Update on the assessment of magnesium status," The British Journal of Nutrition, vol. 99, supplement 3, pp. S24S36, 2008.

[26] G. R. Bailie and S. G. Massry, "Clinical practice guidelines for bone metabolism and disease in chronic kidney disease: an overview," Pharmacotherapy, vol. 25, no. 12 I, pp. 1687-1707, 2005.

[27] P. Bordelon, M. V. Ghetu, and R. Langan, "Recognition and management of vitamin D deficiency," American Family Physician, vol. 80, no. 8, pp. 841-846, 2009. 
[28] A. Levin, B. Hemmelgarn, B. Culleton et al., "Guidelines for the management of chronic kidney disease," Canadian Medical Association Journal, vol. 179, no. 11, pp. 1154-1162, 2008.

[29] G. M. Blake and I. Fogelman, "The role of DXA bone density scans in the diagnosis and treatment of osteoporosis," Postgraduate Medical Journal, vol. 83, no. 982, pp. 509-517, 2007.

[30] D. K. Packham, T. P. Alves, J. P. Dwyer et al., "Relative incidence of ESRD versus cardiovascular mortality in proteinuric type 2 diabetes and nephropathy: Results from the DIAMETRIC (diabetes mellitus treatment for renal insufficiency consortium) database," American Journal of Kidney Diseases, vol. 59, no. 1, pp. 75-83, 2012.

[31] J. P. Doweiko and D. J. Nompleggi, "The role of albumin in human physiology and pathophysiology, part III: albumin and disease states," Journal of Parenteral and Enteral Nutrition, vol. 15, no. 4, pp. 476-481, 1991.

[32] K. Dewitte, A. Dhondt, M. Giri et al., "Differences in serum ionized and total magnesium values during chronic renal failure between nondiabetic and diabetic patients: a cross-sectional study," Diabetes Care, vol. 27, no. 10, pp. 2503-2505, 2004.

[33] P.-C. T. Pham, P.-M. T. Pham, S. V. Pham, J. M. Miller, and P.T. T. Pham, "Hypomagnesemia in patients with type 2 diabetes," Clinical Journal of the American Society of Nephrology, vol. 2, no. 2, pp. 366-373, 2007.

[34] M. Kanbay, M. I. Yilmaz, M. Apetrii et al., "Relationship between serum magnesium levels and cardiovascular events in chronic kidney disease patients," American Journal of Nephrology, vol. 36, no. 3, pp. 228-237, 2012.

[35] J. F. Navarro, C. Mora, M. Macia, and J. Garcia, "Serum magnesium concentration is an independent predictor of parathyroid hormone levels in peritoneal dialysis patients," Peritoneal Dialysis International, vol. 19, no. 5, pp. 455-461, 1999.

[36] A. Baradaran and H. Nasri, "Correlation of serum magnesium with serum parathormone levels in patients on regular hemodialysis," Saudi Journal of Kidney Diseases and Transplantation, vol. 17, no. 3, pp. 344-350, 2006.

[37] M. Ohya, S. Negi, T. Sakaguchi et al., "Significance of serum magnesium as an independent correlative factor on the parathyroid hormone level in uremic patients," The Journal of Clinical Endocrinology \& Metabolism, vol. 99, no. 10, pp. 3873-3878, 2014.

[38] M. R. Khatami, E. Mirchi, Z. Khazaeipour, A. Abdollahi, and A. Jahanmardi, "Association between serum magnesium and risk factors of cardiovascular disease in hemodialysis patients," Iranian Journal of Kidney Diseases, vol. 7, no. 1, pp. 47-52, 2013.

[39] R. K. Rude and H. E. Gruber, "Magnesium deficiency and osteoporosis: animal and human observations," The Journal of Nutritional Biochemistry, vol. 15, no. 12, pp. 710-716, 2004.

[40] M. E. Rodríguez-Ortiz, A. Canalejo, C. Herencia et al., "Magnesium modulates parathyroid hormone secretion and upregulates parathyroid receptor expression at moderately low calcium concentration," Nephrology Dialysis Transplantation, vol. 29, no. 2, pp. 282-289, 2014.

[41] R. Reyes-García, P. Rozas-Moreno, G. López-Gallardo et al., "Serum levels of bone resorption markers are decreased in patients with type 2 diabetes," Acta Diabetologica, vol. 50, no. 1, pp. 47-52, 2013.

[42] M. Kanbay, D. Goldsmith, M. E. Uyar, F. Turgut, and A. Covic, "Magnesium in chronic kidney disease: challenges and opportunities," Blood Purification, vol. 29, no. 3, pp. 280-292, 2010.
[43] J. Bertinato, C. Lavergne, L. J. Plouffe, and H. A. El Niaj, "Small increases in dietary calcium above normal requirements exacerbate magnesium deficiency in rats fed a low magnesium diet," Magnesium Research, vol. 27, no. 1, pp. 35-47, 2014.

[44] Q. Dai, X. O. Shu, X. Deng et al., "Modifying effect of calcium/ magnesium intake ratio and mortality: a population-based cohort study," BMJ Open, vol. 3, no. 2, Article ID e002111, 7 pages, 2013.

[45] J.-H. Huang, L.-C. Tsai, Y.-C. Chang, and F.-C. Cheng, "High or low calcium intake increases cardiovascular disease risks in older patients with type 2 diabetes," Cardiovascular Diabetology, vol. 13, no. 1, article 120, 2014. 


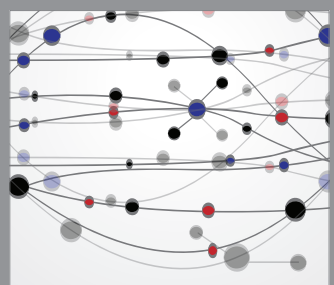

The Scientific World Journal
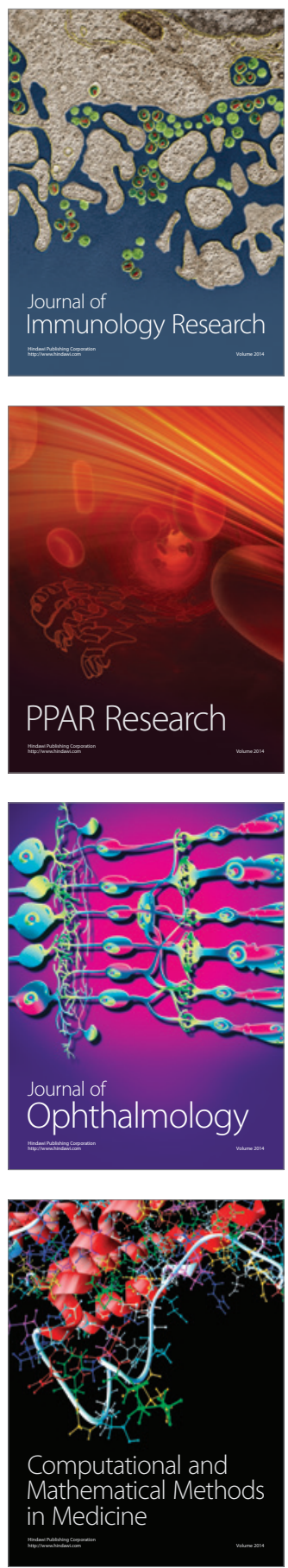

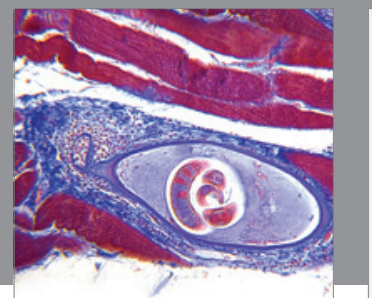

Gastroenterology

Research and Practice
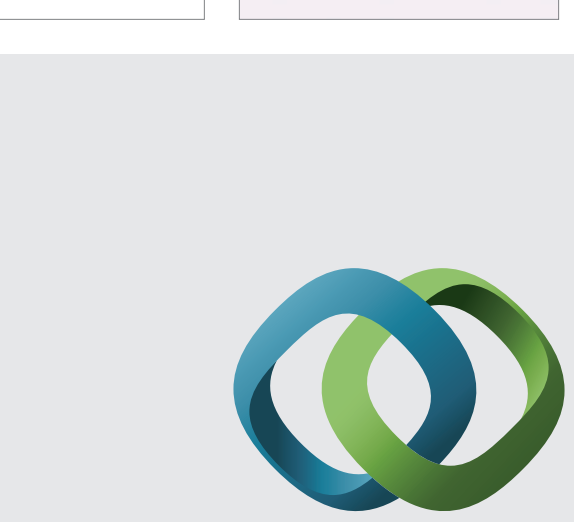

\section{Hindawi}

Submit your manuscripts at

http://www.hindawi.com
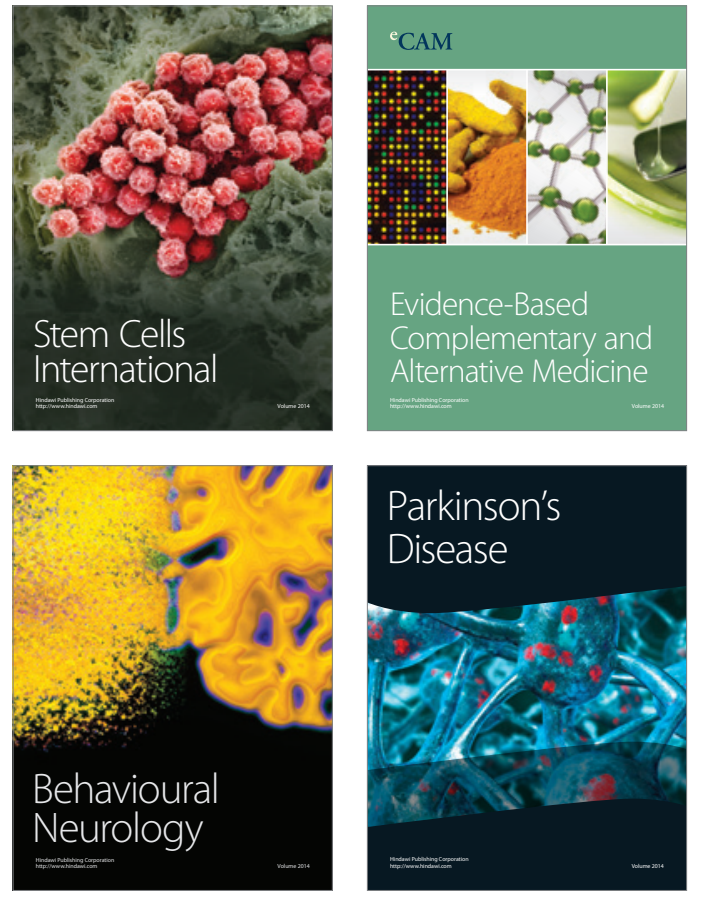
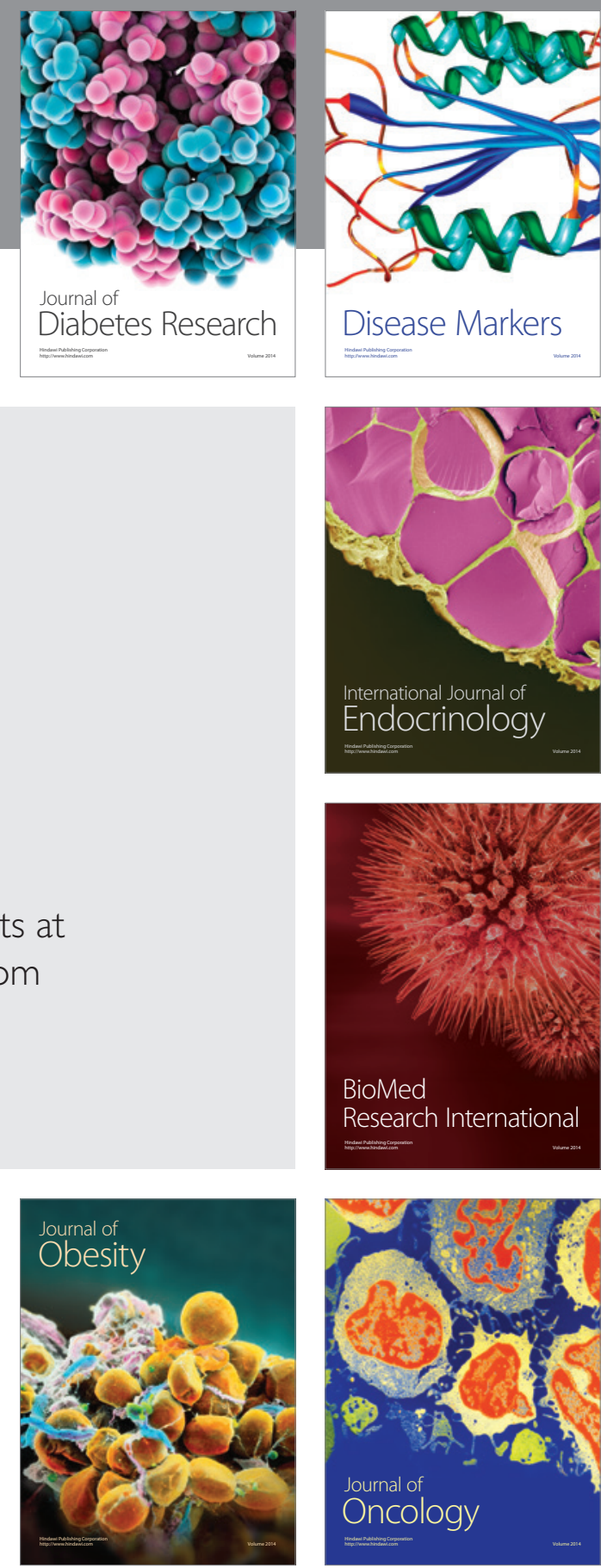

Disease Markers
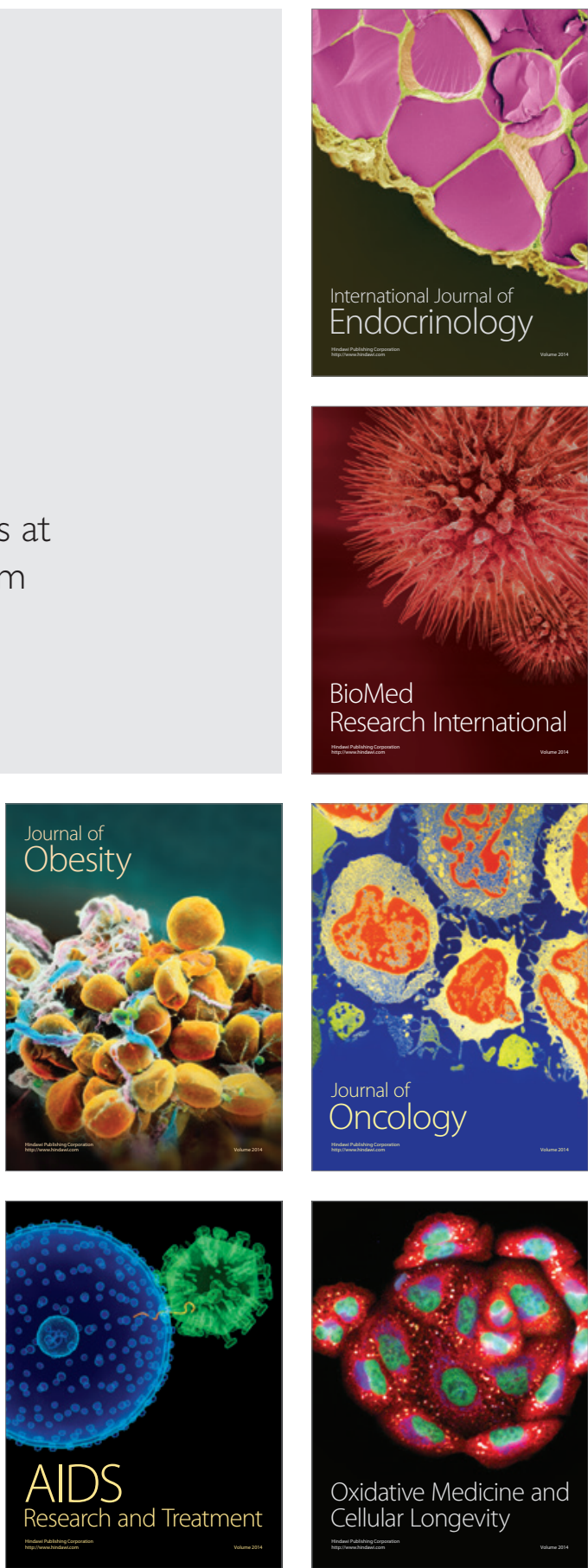